\title{
No Stone Unturned: Newark's Grove Street Cemetery
}

\section{By Barbara Krasner}

\section{DOI: $\underline{\text { http://dx.doi.org/10.14713/njs.v3i2.86 }}$}

This paper examines the history and current status of Newark's Grove Street Cemetery, the first section of which was established in 1885. The cemetery, plagued by deterioration and vandalism for more than 50 years, represents a microcosm of the Jewish immigrant experience, with each headstone telling a story. Given the number of people buried at Grove Street, there are more than 10,000 stories that desperately need saving. Drawing largely upon interviews and papers held at the Jewish Historical Society of New Jersey and site visits, this piece evaluates the cemetery's caretaking efforts and makes recommendations for a path forward.

Nestled between Grove Street and $20^{\text {th }}$ Street on the border of Newark's Vailsburg section

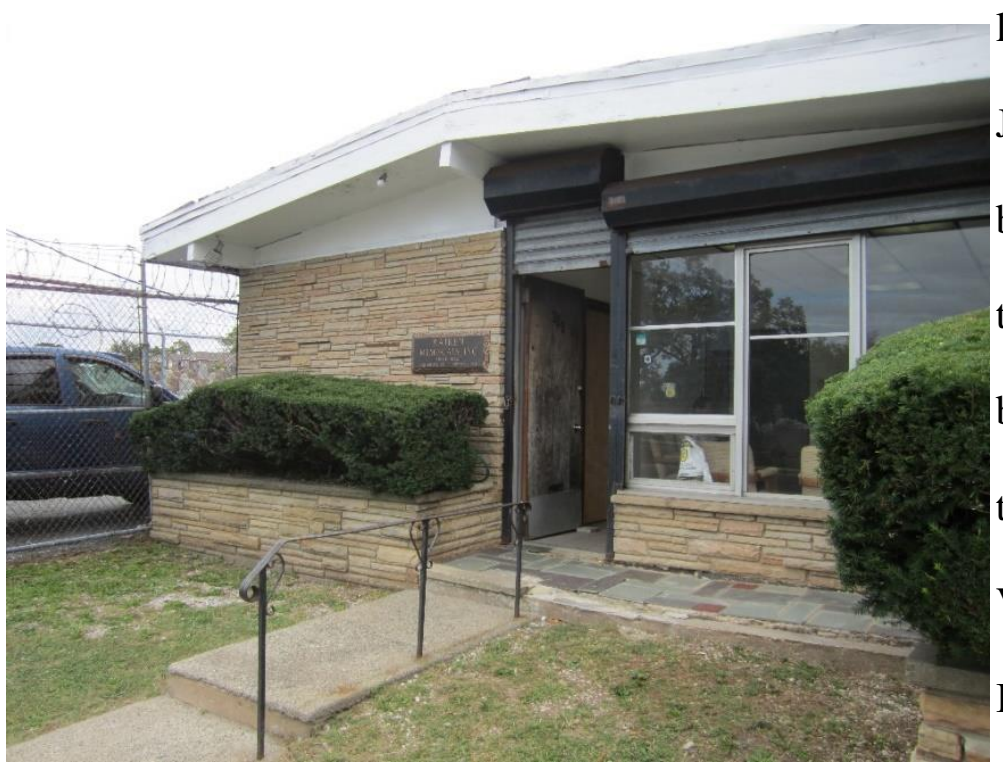

The former Grove Street Cemetery office of Raiken Memorials opens to the public on the annual Newark Cemetery Visiting Day. Note the barbed wire fencing to the left. Photography by the author, 2015. lie the bodies of more than 10,000 Jews. ${ }^{1}$ The Grove Street cemetery is bounded by South Orange Avenue to the south and the Newark/East Orange border via Grain Street to the north. On the $27^{\text {th }}$ Annual Newark Cemetery Visiting Day on September 20, 2015, Ira Epstein, who inherited his father's cemetery caretaking business, Sanford B. Epstein, Inc., and others manned the office building that was once home

\footnotetext{
${ }^{1}$ Alice Perkins Gould, The Old Jewish Cemeteries of Newark (Teaneck, NJ: Avotaynu, 2005), 84.
} 
to their business. They fielded visitor questions but could not adequately respond with any detail to queries about locations of the interred. A woman entered with a list of entries. Two hours later, she was still searching. Another man came into the office holding a piece of legal paper. On it his father had scribbled the locations of their family members interred in the cemetery. He, too, was looking for his connection to the past. When I asked about Ain Yankov, the section where my great-grandparents, Bryna and Mordechai Krasner are buried, I was told to look in Section 12. Both Epstein and another office worker authoritatively said that Ain Yankov was part of another section, Congregation Anshe Russia. They did not check documentation. They did not consult a website. Their suggestion, while well intentioned, was wrong. I could not find my greatgrandparents in this or adjoining sections. Eventually, I used the cemetery burial database of JewishGen.org, based on the work of Alice Perkins Gould, author of The Old Jewish Cemeteries of Newark, and former leader of a grass roots action sponsored by the North Jersey Jewish Genealogical Society to inscribe Grove Street headstones. I learned Bryna and Mordechai were buried in Section 16, which was Anshe Warshaw. ${ }^{2}$ This confusion explained the long and futile search of Section $12 .{ }^{3}$ I spotted about ten people searching the grounds for their deceased loved ones.

All of us that day searched for connections to the past. Grove Street holds the key. The cemetery is now open to visitors just one day each year on the Sunday between Rosh Hashonah and Yom Kippur, the holiest days of the Jewish calendar. Barbed wire tops the cemetery's fences. Many gravestones are overturned or broken. These hazards, combined with broken bottles and

\footnotetext{
${ }^{2}$ Gould published a map denoting the names of each section in detail. The guide published for the annual visiting day does not include that detail.

${ }^{3}$ Epstein did not refer me to the JewishGen database. Rather, a former volunteer from Gould's initiative did.
} 
other trash, make it treacherous to traverse the cemetery's thirty-seven sections. Police line the borders of the cemetery on visiting day for safety reasons.

Despite the vandalism, Epstein says of the Grove Street Cemetery, "This is the way it should be, like a museum,"4 echoing graveyard historian Lynette Strangstad's view that "early graveyards are outdoor museums." ${ }^{5}$ As such, the Grove Street cemetery, a conglomeration of plots purchased by now defunct synagogues, organizations, and societies, represents a microcosm of the

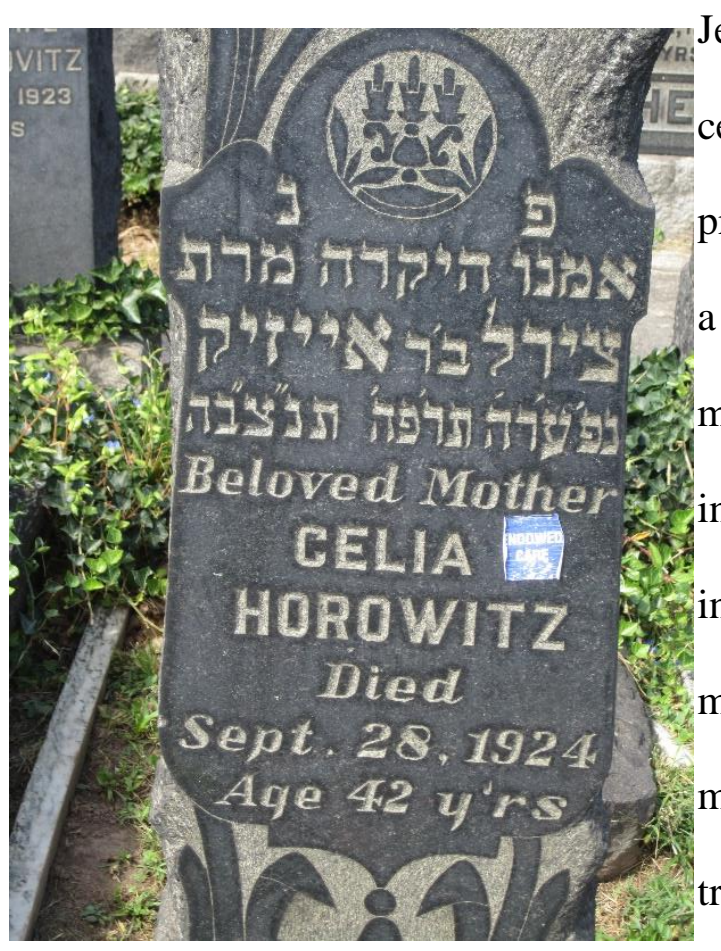

By 1924, next of kin and engravers used a combination of traditional Hebrew and English on headstones. Note the endowed (perpetual care) sticker on this grave of Celia Horowitz, born Tsirel, daughter of Aizyk. The headstone also shows a particular style of monument to resemble a tree trunk. Photograph by the author, 2015.
Jewish immigrant experience. At the same time, the cemetery presents an opportunity, as historic preservation scholar Ned Kaufman explains, to develop a storyscape, to "collect interesting stories, meaningful memories or intense feelings of attachment." ${ }^{, 6}$ Headstone inscriptions convey the degree of assimilation. For instance, mid-to-late nineteenth century headstones might be engraved purely in Hebrew. Later, headstones may use a combination of Hebrew and English. The transition to two languages may indicate assimilation as well as attachment to religious custom.

Each headstone relays a story waiting to be discovered. For example, the mausoleum of Rabbi Aaron Cohen in the Anshe Warshaw section on $20^{\text {th }}$

\footnotetext{
${ }^{4}$ Ira Epstein, interview by author, Newark, September 20, 2015.

${ }^{5}$ Lynette Strangstad, A Graveyard Preservation Primer (Nashville, TN: American Association for State and Local History, 1988), 5.

${ }^{6}$ Ned Kaufman, Place, Race, and Story: Essays on the Past and Future of Historic Preservation (New York and London: Routledge, 2009), 3.
} 
Street distinguishes itself from other gravesites. Rabbi Cohen was born in Vilna in 1858. When he came to America, he became the rabbi of the Anshe Warshaw Synagogue on Bedford Street in Newark. His mausoleum, the only one in the Grove Street Cemetery, has been stripped of its stained glass windows and its bronze doors. Nevertheless, it has become a marker to guide visitors to their loved ones' gravesites.

Common gravestone information may include the following: given name, father's given name, date of birth, date of death, age at time of death, and marital status. Symbols engraved into the stone may reveal membership in the priestly caste (shown by extended fingers on two hands, a Kohane) or a water pitcher to indicate a Levite, assistant to the priests. In both these cases, the Hebrew inscription may confirm the association with either Hacohen or Halevi. A lamb monument or symbol denotes someone who died young, as does a broken branch or flower. A menorah typically identifies a female and a Star of David a male. ${ }^{7}$

Holistically and historically, Grove Street provides a narrative of a community partitioned by synagogues, lodges, and societies. This is a narrative worth preserving, although its current state will make any preservation efforts challenging. This article provides the background of the individual sections that comprise Grove Street Cemetery, the preservation efforts of the Epsteins and the Jewish Community Foundation of Federation of Greater MetroWest, and articulates recommendations for future preservation. Documentation indicates that at several points in this cemetery's history, grass roots and organized efforts sought to preserve the integrity of this cemetery. Without a fully funded and championed initiative owned by the community and the city of Newark, the deterioration and vandalism that has been occurring for the last fifty years will also persist.

\footnotetext{
${ }^{7}$ For more in-depth discussion of Jewish cemetery symbols in America, see David M. Gradwohl's Like Tablets of the Law Thrown Down: The Colonial Jewish Cemetery in Newport, Rhode Island (Ames, Iowa: Sigler, 2007).
} 
The story of Newark's Jewish community commenced with the arrival of Louis Trier from Germany in 1844. Thousands followed to escape religious persecution, pogroms, or just to find a better way of life where Jews could be franchised and have the right to life, liberty, and the pursuit of happiness. By 1911, 50,000 Jews inhabited Newark. Newark's Jewish population reached its peak in 1948 when the city was home to 59 synagogues and between 60,000 and 75,000 Jews. ${ }^{8}$ B'nai Jeshurun, Newark's first synagogue, was officially founded by German-Jewish immigrants in 1848. Polish-Jewish immigrants did not feel comfortable attending B'nai Jeshurun. They founded their own synagogue, B'nai Abraham (“Sons of Abraham”), in 1855. Former members of B'nai Jeshurun established a third synagogue established in 1860. They called it Oheb Shalom ("Lovers of Peace").

At some point, these congregations needed space to bury their dead. The first recorded Jewish burials in Newark occurred in 1854 at the Belmont Cemetery, then a wooded area on the outskirts of the city now within the boundaries of Hillside township. The Mendelsohn Benevolent Society and Congregation B'nai Jeshurun ("Sons of the Righteous") purchased a plot for burials in 1847. Burials there ceased in 1862 and in 1899 the bodies were moved to the congregation's new cemetery in Hillside. In the twentieth century, Belmont Cemetery was called the Old Jewish Cemetery. B'nai Jeshurun sold the land in 1922. An apartment complex now stands on the site. The first recorded burial in the B'nai Abraham cemetery was of five-year-old Ella Cohen, daughter of Joseph Cohen, in 1861.

Oheb Shalom's first burial took place in 1866 at a cemetery that stands at South Orange Avenue, and because it bought the property from B'nai Abraham, abuts the B'nai Abraham

\footnotetext{
${ }^{8}$ Robert Wiener, "Shul Traces Community's Past and Future in Day-Long Tour of Jewish Newark." NJJewishNews.com. April 26, 2007. Accessed October 23, 2015. http://njjewishnews.com/njjn.com/042607/mwShulTraces.html
} 
Cemetery. Next to the B'nai Abraham Cemetery is another cemetery, Union Field, largely located in Irvington. The new Oheb Shalom cemetery on Broad Street in Hillside was established in the early 1900s on land purchased from Lyon's Farm.

The process of buying and selling cemetery property between Jewish congregations and organizations repeated itself many times to either create or dispose of unnecessary land. These arrangements exemplify Grove Street Cemetery, coincidentally situated across from the Holy Sepulchre Cemetery, a system of orderly gravesites maintained by the Roman Catholic Archdiocese of Newark that was initially established in 1859. In contrast, Grove Street Cemetery sections recall the mishmash of remaining gravestones found in central and Eastern Europe. Navigating through Grove Street resembles that of a maze or labyrinth. Gates range in architectural style from the simplistic to the ornate.

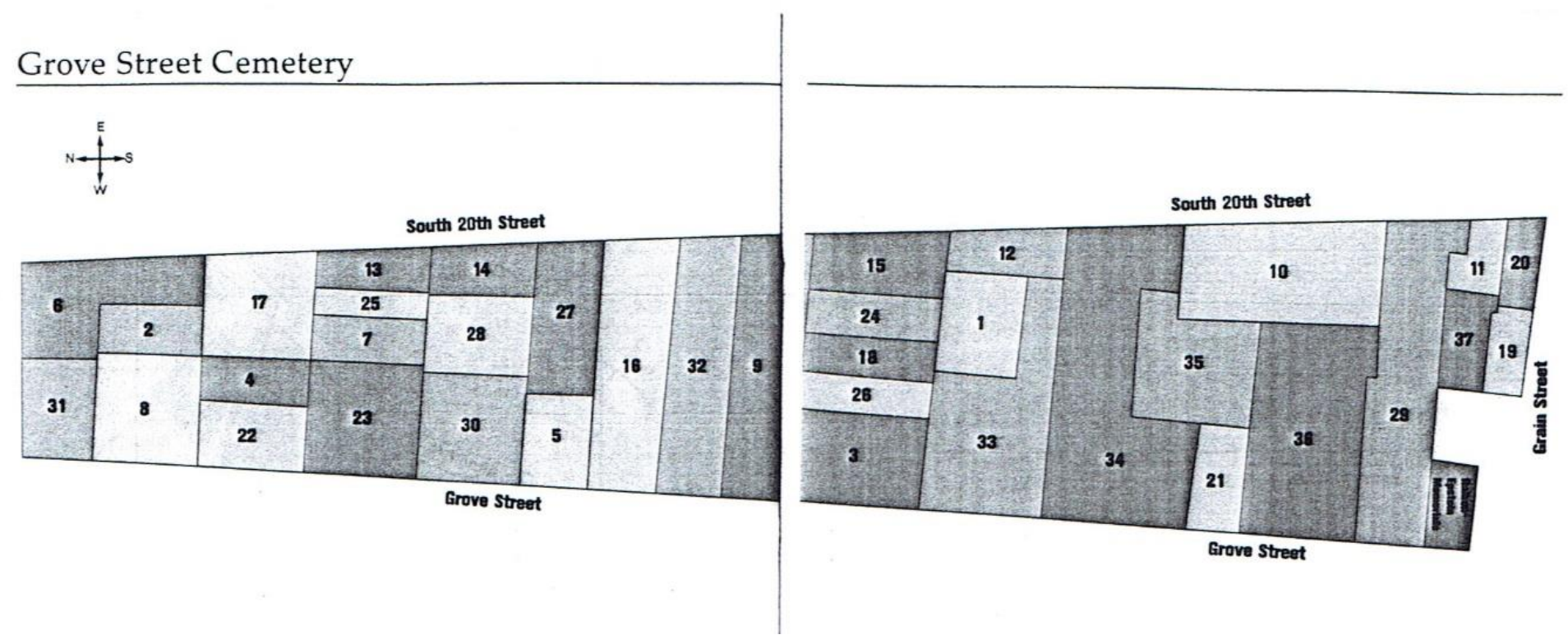

Grove Street Cemetery Sections:

1-Admiral Sampson Lodge No. 192

2-Austria-Hungary Congregation Tifereth Israel

3-Baron Rothschild Lodge No. 105

4-Congregation B'nai Jacob 
5-Brisker Congregation Grove

6-Brisker Congregation So. $20^{\text {th }}$ Street

7-Chechanovitzer KUV

8- Congregation Ahawas Achim B'nai Jacob and David (AABJ \&D)

9- Congregation Adas Israel and Mishnayes - Grove Street

10 - Congregation Adas Israel and Mishnayes-South $20^{\text {th }}$ Street

11 - Congregation Adas Israel-South $20^{\text {th }}$ Street

12 - Congregation Anshe Israel-South $20^{\text {th }}$ Street

13- Congregation Anshe Lubovitz

14- Congregation Anshe Romania

15- Congregation Anshe Russia No. 2

16- Congregation Anshe Warshaw

17- Congregation B'nai Zion-Roseville

18- Congregation. Chevra Tillum

19-Congregation Sinai Torah-Chaim

20 - Congregation Toras Emes - 20 ${ }^{\text {th }}$ Street

21- Congregation Toras Emes-Grove Street

22-Erste Bolechover

23-Gerechtigeit Lodge

24-Guardians of Faith/Shomrei Emunah Congregation

25-Harrison Lodge

26-Harrison Shule

27-Hebrew Free Burial

28-Independent Newarker

29-Israel Krankenunterstitzungsverein (KUV)

30-Kurlander Lodge

31-Orange City Lodge

32-Russian \#1- Congregation Knesseth Israel

33-Russian \#3 - Congregation Knesseth Israel

34-Russian \#4, 5- Congregation Knesseth Israel

35-Russian \#6- Congregation Knesseth Israel

36-Workmen's Circle-Grove St.

37-Workmen's Circle-So. $20^{\text {th }}$ Street

This list and map of the Grove Street Cemetery's 37 sections consist of synagogues, KUVs, and lodges. Courtesy Jewish Community Foundation of Greater MetroWest, NJ, “27th Annual Newark Cemetery Visiting Day,” 2015. 

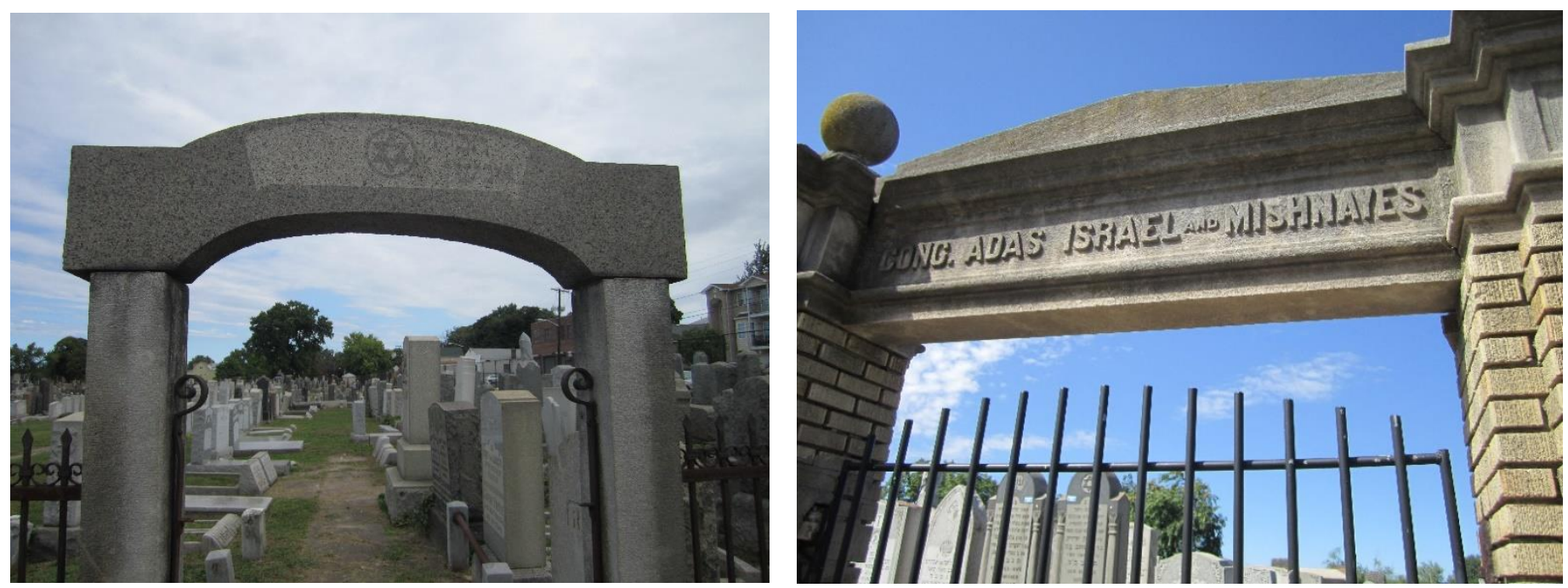

Gates and entries to sections of the Grove Street Cemetery are, for the most part, ineffective and/or illegible. Photographs by the author, 2015.

Synagogue burial societies and town-based societies known as landsmanshaftn initially paid for their Grove Street Cemetery plots. Former residents of a certain shtetl (village) or group of shtetlach formed a landsmanshaft — a Jewish immigrant benevolent society - to help them assimilate, acculturate, and socialize. But the societies also served another important function. Within each shtetl back home, a burial society or chevra kadisha cared for the proper interment, according to religious custom. Examples of congregations at Grove Street include Congregation Anshe Romania, Congregation Anshe Russia, and Congregation Toras Emes. Examples of landsmanshaftn include the Chechanovitzer Krankenunterstitzungsverein or KUV, comprised of people from Chechanovitz, Poland (also known as Ciechanowiec in Polish). A KUV literally means "sick benefit society" and was similar to a benevolent society or mutual aid society. The Israel KUV was the first to establish a section of Grove Street in 1885 . These could have been the nine hat makers who organized a KUV, discussed in The Essex Story, a history of the Jewish community in Essex County, and who served as a model for hundreds of other such groups. ${ }^{9}$

\footnotetext{
${ }^{9}$ Jewish Education Association of Essex County, Newark, New Jersey, The Essex Story: A History of the Jewish Community in Essex County, New Jersey (Newark, NJ: Jewish Education Association, 1955, reprinted in 1976), 41.
} 
Lodges also purchased plots at Grove Street. These included the Workmen's Circle, or Arbeiter Ring, the Admiral Sampson Lodge No. 192, and the Baron Rothschild Lodge No. 105.

Alice Perkins Gould writes, "Many of the sections are listed with various names and boundaries, depending upon whether one is looking at old city tax maps, caretakers' diagrams, or funeral directors' charts." 10 This confusion about section names is the result of the transition of cemetery section ownership during the course of Grove Street cemetery's 130-year history. Congregation Ahawas Achim B'nai Jacob and David (or AABJ \& D) exemplifies the confusion. Sounding much like the name of a law firm, the congregation began in 1886 as Ahawas Achim Anshe Warshe. It then merged with B'nai Jacob in 1935 and with B'nai David in 1966. Gould writes, "As other orthodox synagogues went out of existence, it assumed the care for their sections in the Grove Street Cemetery and in the other cemeteries in Newark."11

The names of the thirty-seven sections reflect their Jewish heritage in Hebrew, Yiddish, German, or assimilated English. By purchasing plots and overseeing burials, individual communities demonstrated a level of care for their own members, mimicking the communal practices of their former European hometowns.

Grove Street's interred reflect successful synagogues, such as Congregation Adas Israel and Mishnayes, which originated in Newark and ultimately followed Newark's Jews to the suburbs, specifically Springfield. Anshe Russia was another flourishing congregation, as were Toras Emes, Esterich Hungary (Austria-Hungary), Adas Israel/Ein Yaakov ${ }^{12}$ (which later merged and became Knesseth Israel), the Brisker Shul, and Ahavas Achim/Anshe Warshaw. ${ }^{13}$ Established in 1873, Congregation Adas Israel (on Newark's Bedford Street) merged with Congregation

\footnotetext{
${ }^{10}$ Gould, The Old Jewish Cemeteries of Newark, 16.

${ }^{11}$ Gould, The Old Jewish Cemeteries of Newark, 23.

${ }^{12}$ Ein Yaakov goes by many names, including Ain Yankov.

${ }^{13}$ Since many of these names are transliterated from Hebrew or Yiddish, spellings vary.
} 
Mishnayes on Jones Street in 1911. The new combined congregation moved into the previous home of Oheb Shalom on Prince Street. ${ }^{14}$

Some of the largest sections of the Grove Street Cemetery belong to Anshe Russia, which formed in 1885 . Members paid $\$ 6$ annual dues to cover expenses and contribute to a fund to buy cemetery ground. ${ }^{15}$ In November 1888 , the congregation empowered a committee to buy four lots on Grove Street for its cemetery. A twenty-fifth anniversary commemorative booklet explained the importance of the cemetery for historical purposes based on the disappearance of records for cemeteries "on the other side." The author of that booklet, Abraham Ravitz, wrote, "For that reason many Jewish investigators went to the old cemeteries and by examining the tombstones and monuments were able to learn something about the people that had lived there, and these findings they recorded in books."16

Keeping records has been the responsibility of the Margolis-Orlovsky-Rubin-Epstein family since 1913. Members of the Epstein family have been caretakers of Grove Street and other northern and central New Jersey cemeteries since before 1911, when immigrant Moshe (Morris) Margolis's brother-in-law Samuel Orlovsky joined Morris and his wife, Sarah, in the business. Responsibility changed hands from one family member to another until 1982 when Sanford Epstein and his daughter bought the Raiken Monument business. ${ }^{17}$ The family now cares for fourteen Jewish burial grounds in Newark and Elizabeth in addition to cemeteries in Kenilworth, Bridgewater, South Plainfield, and Mount Freedom. As the New Jersey Jewish News stated in

\footnotetext{
${ }^{14}$ Prince Street was the heart of the Third Ward, where the majority of Jewish immigrants lived.

${ }^{15}$ Gould, The Old Jewish Cemeteries of Newark, 16.

${ }^{16}$ As quoted in Gould, The Old Jewish Cemeteries of Newark, 17.

${ }^{17}$ Debra Rubin, “Who's Taking Care of the Cemeteries?" MetroWest Jewish News, June 10, $1993,36$.
} 
Epstein's June 2014 obituary, “Epstein was a go-between among surviving relatives and memorial parks that had often been left behind by communities that had moved elsewhere."18

Epstein's daughter and Raiken-Epstein Memorials owner, Fern Epstein, says all these synagogues and organizations "had their little space. They all kept their own records. And they had the maintenance companies doing the labor." The decentralized nature of this arrangement made it difficult for a maintenance company to manage anything but the physical property. Fern Epstein says, "They had no sense of putting some money away for the future of the cemeteries. And there are many, I don't know specifics, but I do know that there are many that merged or evolved into other synagogues and they took whatever dues or money they had and they moved. So the cemetery became the low man on the totem pole..."19

Other Jewish cemeteries in the area, such as Beth Israel in Woodbridge, have computerized access to burial records and can quickly locate the burial site for interested parties. At Oheb Shalom, no one was on the premises to ask, so one must rely on family oral history or previous visits. That also holds true for Grove Street. The Raiken-Epstein monuments and the Sanford B. Epstein cemetery caretaking businesses moved from their office on Grove Street to Kenilworth, presumably for safety reasons, and are only on site in the Grove Street office on the annual visiting day. (Epstein's office had been completely destroyed by vandals in 1979.)

Grove Street Cemetery offers genealogical riches and a way for descendants to pay respects. In May 2014, the New Jersey Jewish News featured an article about genealogist Harold Kravis, a Livingston resident, whose ancestors once belonged to Anshe Warshaw. He told the reporter, "I started looking in 2001 and I found his (great-grandfather Morris Kravitz from Poland)

\footnotetext{
18 Johanna Ginsberg, “Cemetery Guardian Sanford B. Epstein, 78,” NJJewishNews.com, June 11, 2014, accessed October 23, 2015, http://njjewishnews.com/article/23276/cemetery-guardian-sanford-b.-epstein-78\#.VirtdH6rSM8.

${ }^{19}$ Fern Epstein, interview by author, Kenilworth, October 19, 2015.
} 
grave at the Anshe Warsaw (sic) Cemetery on Grove Street. But I am still looking for the memorial plaque." ${ }^{20}$ Four years earlier, Elaine Bornstein stood in the rain with her son at the grave of an uncle she had never known. She told a New Jersey Jewish News reporter, "Eighty-five years he's been gone, and he still has people coming to see him. That's something." ${ }^{21}$ Bornstein recalled coming to uncle Max Kessler's grave for years when she was a child. He had drowned while saving a child at Coney Island. The Bornsteins joined a few hundred people at the 2010 annual Newark

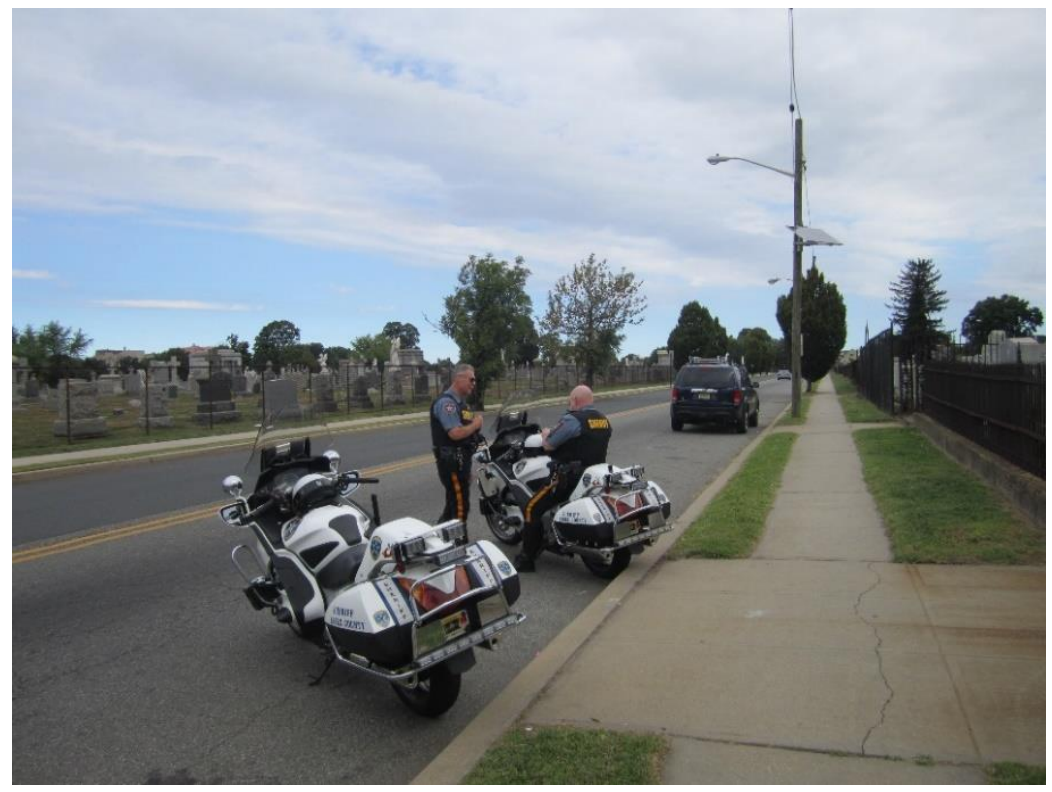
Cemetery Visiting Day. ${ }^{22}$ They come to tend neglected graves and to honor their ancestors, saying Kaddish, the prayer for the dead, and placing stones on the tops of headstones under the watchful eye of police. ${ }^{23}$ They venture to this gritty neighborhood, because as

Members of the Essex County Sheriff's Department police the area surrounding the Grove Street Cemetery on the annual visiting day, the Sunday between the Jewish New Year and the Day of Atonement, the holiest days of the year. Grove Street Cemetery is to the right; Holy Sepulchre is to the left. Note the difference in the gates between the two cemeteries. Photography by the author, 2015.

Bornstein states, "We couldn't not come." Rabbi Steven Kushner, religious leader of Bloomfield's

\footnotetext{
${ }^{20}$ Robert Wiener, "Going to the Wall for Lost Plaques," NJJewishNews.com, May 14, 2014, accessed October 23, 2015, http://njjewishnews.com/article/22926/going-to-the-wall-for-lost-plaques\#.ViruKn6rSM8.

${ }^{21}$ Johanna Ginsberg, "Newark Graves Evoke Memories of Another Time," NJJewishNews.com, September 15, 2010, accessed October 23, 2015, http://njjewishnews.com/article/1931/newark-graves-evoke-memories-of-anothertime\#.VirsOX6rSM9.

${ }^{22}$ Fern Epstein debates the number. She says there were never hundreds of people at the cemetery on visiting day.

${ }^{23}$ Sanford Epstein served as a constable in Irvington about forty or more years ago. He became familiar with a kind of fraternal order of Jewish police there. It was his idea to have the visiting day secured by local police volunteers.
} 
Temple Ner Tamid offers, "By visiting the graves of our ancestors we not merely honor their memories but affirm their dreams."24

At the center of Grove Street Cemetery's visitation is the Community Relations Committee (CRC) of the Jewish Community Foundation of the Jewish Federation of Greater MetroWest NJ, headquartered in Whippany. It has been organizing the annual Newark cemetery visiting day since 1988 .

Reference to deteriorating conditions of the Grove Street Cemetery has been made in documents since at least 1965, when the CRC conducted a formal study to scope out the

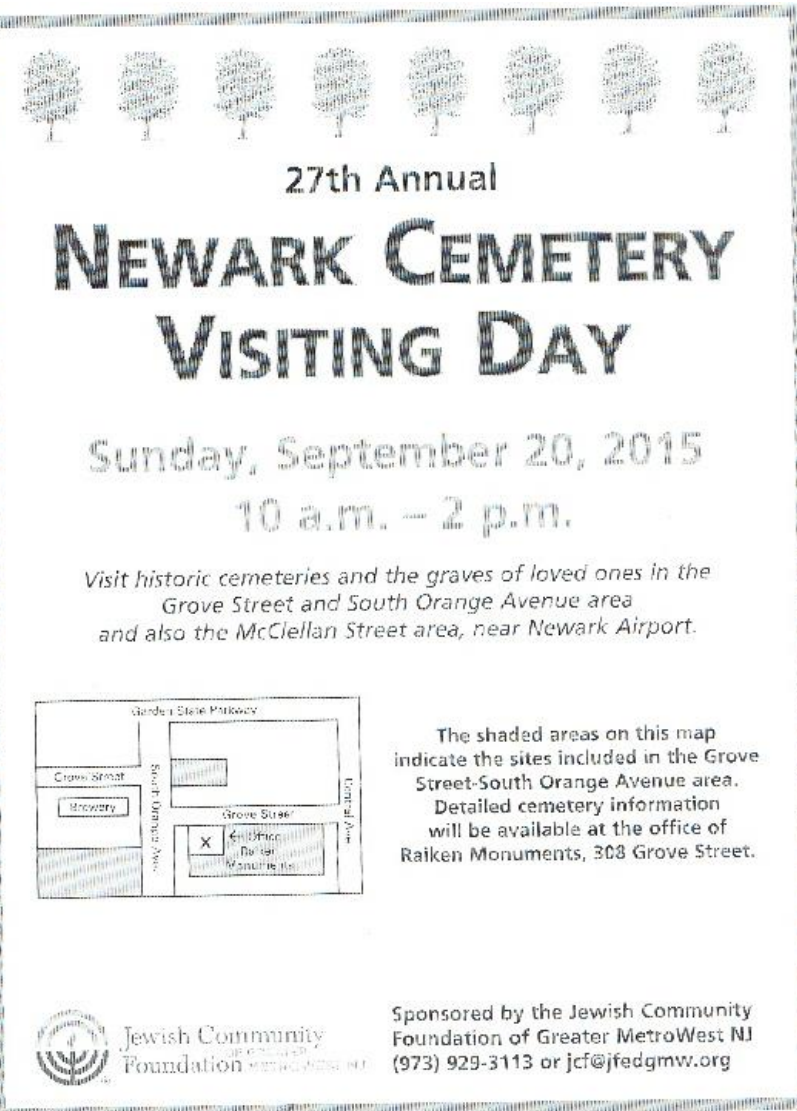

Since 1988, MetroWest has been organizing an annual visiting day to the Newark Jewish cemeteries. Courtesy Jewish Community Foundation of Greater MetroWest NJ.

"cemetery problem." The study recommended a title search to identify ownership of each of the cemetery plots. The CRC concluded in 1966 that rehabilitation would prohibitively run into thousands of dollars. Meyer Fine, CRC Executive Secretary, stated in a 1975 memo, "It became clear that the untidy conditions which initially engaged our concern are merely symptoms of a more serious and complex underlying set of problems." A main question was who should bear the responsibility for the costs. Fine summarized that it was ultimately the responsibility of the families who purchased the plots. He wrote, "The single-most important factor responsible for the

\footnotetext{
${ }^{24}$ Ginsberg, "Newark Graves."
} 
deteriorated physical conditions is the large number of abandoned graves owned by individual families who are either deceased, have moved from the area, or who refuse, for a variety of reasons, to continue their financial responsibility on an annual basis. ${ }^{25} \mathrm{He}$ warned against a one-time cleanup that would ultimately not solve the underlying problem.

In May 1967, the CRC recommended hiring a cemetery specialist to again research the problem. The proposal was tabled due to lack of funds. Five years later, the CRC engaged volunteers from the New Jersey National Guard to clean up three Newark cemeteries, which did not include Grove Street. Even with news coverage in the Jewish News, the effort failed to catalyze community involvement. Two years after that, the CRC assigned "the cemetery problem" to its Committee on Jewish Security and Civil Rights. The committee's thirty-three-page report raised more questions than it answered. Fine concluded that another task force was required to continue the work of the committee.

The CRC commissioned a task force on cemetery conditions in the spring of 1976. Its mission was three-fold: (1) examine the problem of the neglected cemeteries; (2) study the facts and the issues involved; and (3) propose a possible solution to the problem. The task force consisted of heads of synagogue burial societies, funeral home directors, and monument makers. Some members were lawyers or rabbis. Its chair was Jack Leibowitz of Millburn. A subset of the task force conducted a walking tour. They found many gravestones knocked down by vandals or toppled by a combination of weak foundations and strong winds. In some cases, grass and brush had grown several feet high. Litter dirtied the sidewalks and evidence of brush fires was apparent.

The task force then developed a plan of attack. It defined ownership in three categories: (1) abandoned cemeteries; (2) organizations that exist but do not function; and (3) organizations still

\footnotetext{
25 Jewish Historical Society of New Jersey, Task Force on Cemetery Conditions, Folder III, 1968-1977, Meyer Fine, "The Neglected Jewish Cemeteries in Newark," August 27, 1975.
} 
active and still actively maintaining their grounds. Statements of projected income and operating expenses appended the plan as did a timeline calling for action from November 1978 to September 1979.

In one of its first activities, the task force contacted the New Jersey State Attorney General's office to solve the cemetery problem. The result was a statement that the Grove Street cemetery did not fall under the jurisdiction of the New Jersey Cemetery Board, although interments were still taking place, and were, therefore, not subject to its standards.

The task force then mailed fifty surveys to chairmen of cemetery organizations. Fewer than a dozen responded. Those who did noted caretaker Max Rubin's ineffectiveness and their desire not to pay him more than the minimum if anything at all. Phone call follow-ups confirmed the difficulty of reaching the appropriate people. Five cemetery chairmen and rabbis convened. But it was soon clear that no organization wanted to pool resources. The Federation would have to step up, play a role, and figure out a way to deal with Rubin's pending retirement and the loss of his intellectual property. Legend has it he knew where every grave was.

The task force recommended to the Federation that another committee be established to bring together representatives of various landsmanshaftn, cemetery and synagogue organizations to maintain the cemetery on Grove Street. A subcommittee met with a construction firm and a fencing company to obtain additional information about repairs and replacements of fences and pathways. Rubin was still carrying out about 80-100 interments a year at Grove Street around this time.

In July 1977, the task force looked for analogs of its situation in other Jewish communities, including Cleveland, Detroit, Chicago, and Boston. It thought Cleveland's situation most closely resembled Newark's. A small grass roots effort got underway. The confirmation class of Temple 
Beth Shalom in Livingston announced "Operation Cemetery Clean-up.” But ultimately, Meyer Fine was right. A one-time clean-up could not resolve the issues.

In September 1978, Daniel Galanty of Iselin wrote to Arnold Blum of Congregation Ahawes Achim B'nai Jacob and David in West Orange to complain about the conditions of Grove Street. Blum replied:

...these are problems that are not easily solved and I would like to explain some of them to you so you can appreciate the magnitude of the situation...their origin dates back more than 75 years and since that time many of these synagogues and organizations have disappeared from existence, no longer function or if still around do not care to recognize their obligations to maintain the sacred ground that their predecessors founded. ${ }^{26}$

Soon after, Jack Nover of South Orange sought assistance from the CRC. He had met with Newark landmark officials who encouraged him to write a proposal for the Grove Street Cemetery. The proposal, the officials told him, should include the history of the Jews in Newark. A Jersey City Christian cemetery provided a precedent. The CRC responded to Nover in November 1978: “several of our Community's Jewish cemeteries have been victims of the same vandalization (sic) and desecration that Temple B'nai Abraham has experienced...we are now beginning to explore a permanent solution to this psychological and morally debilitating problem." ${ }^{27}$ Records do not indicate that Nover ever submitted a proposal.

It was clear to Task Force members that Max Rubin received little income and was not able to do more than a superficial job in maintaining the cemetery property. The members also understood that the surrounding neighborhood had deteriorated and that vandalism had been difficult to control. The Jewish Federation proposed to buy Rubin's assets, including real estate

\footnotetext{
${ }^{26}$ Jewish Historical Society of New Jersey, Task Force on Cemetery Conditions, Folder 1, 1978-1979, letter from Arnold Blum to David Galanty, October 9, 1978.

${ }^{27}$ Jewish Historical Society of New Jersey, Task Force on Cemetery Conditions, Folder 1, 1978-1979, letter from Fredda B. Smith to Jack Nover, November 15, 1978.
} 
property, and then hire him and his secretary "as the most feasible method of managing the Jewish Cemetery in the Newark area." The Federation then proposed to collect fees from the burial organizations plus an annual maintenance fee on each grave. Further, it would collect fees for opening graves and setting foundations. But it admitted, "There would have to be a great deal of research done on who actually owns the abandoned cemeteries and who could have the right of sale." ${ }^{28}$ There is no evidence of the proposal's acceptance.

Archival information does not go much beyond this point. A photographer noted in a 2015 interview that when he took photos of Grove Street in the 1970s showing the cemetery's deplorable condition, it sparked a clean-up. The Jewish News carried a brief feature about his photos in March 1976. ${ }^{29}$ The feature stated, "The Grove Street Cemetery is a legacy of an immigrant people whose presence in a growing community was part of the dynamics of growth itself... what began as 'perpetual care'...became perpetual deterioration and desecration. What should have been a treasured landmark now languishes." 30

Despite all the efforts over the last fifty years, the "cemetery problem" persists. In 2013, the Federation established the Community Association for Jewish At-Risk Cemeteries to address the growing concerns regarding the "Newark Jewish Historical Cemeteries." The association is an outgrowth of the Beth El Memorial Park Foundation created in 1988 as an outcome of a court case. Rabbi Steven Kushner of Temple Ner Tamid in Bloomfield serves as president of the foundation and has served on its board since its establishment. Interest from foundation investments fund repairs of damaged areas and re-erection of fallen headstones. The foundation also funds the annual visiting day.

\footnotetext{
${ }^{28}$ Jewish Historical Society of New Jersey, Task Force on Cemetery Conditions, Folder 1, 1978-1979, memo from Joseph Huber to Jack Leibowitz, Harriet Perlmutter, and Jacob Goodstein, October 16, 1979.

29 The photographer, Fred Rosenberg, could not be reached for comment.

30 "Perpetual Care: The Grove Street Cemetery, Newark," Jewish News, April 1, 1976, 2.
} 
The work of the association may still be insufficient to address a growing and perhaps terminal cancer on the cemetery. Deteriorating conditions at Grove Street are still evident. According to Judy Salomon, one of Gould's original volunteers who visited the cemetery again in 2015, "It has been a few years, three to four, since I have been out there and the graves are in worse shape. More stones toppled. Epstein moved his office to Kenilworth shortly before we finished the documentation. I think that is part of the reason."31
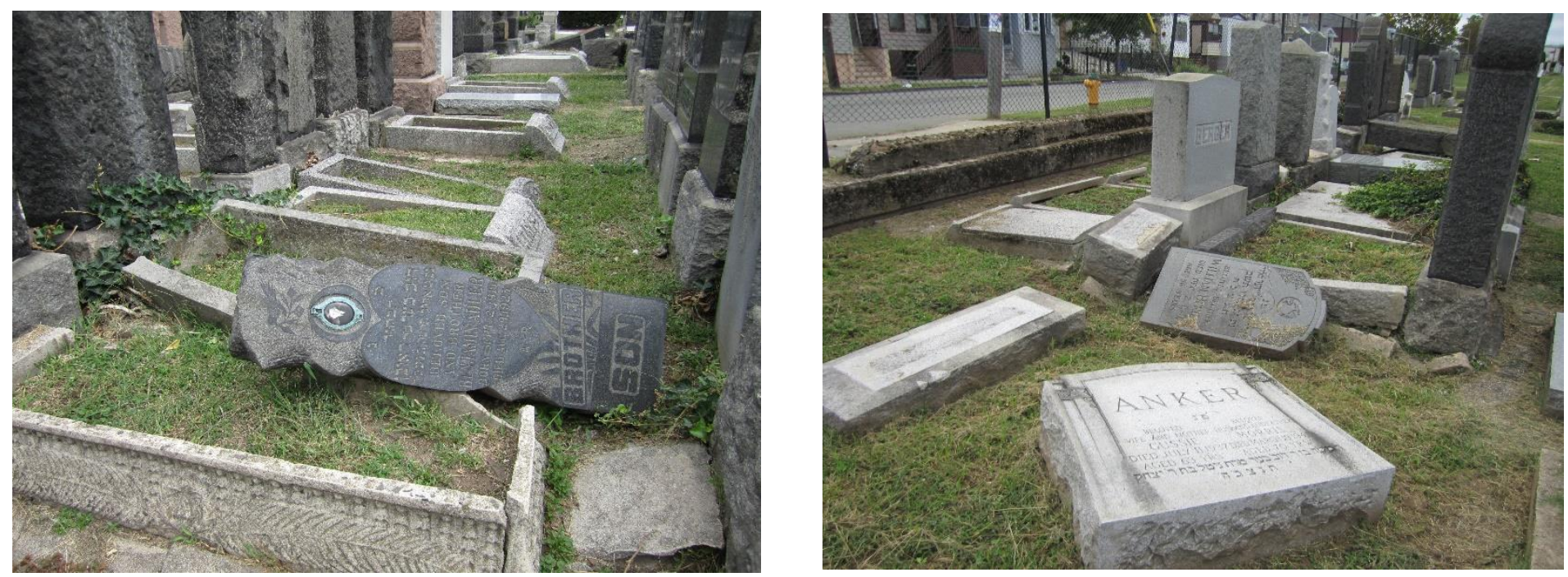

A trip to Grove Street Cemetery in September 2015 on annual visiting day yielded views of these toppled tombstones. Photographs by the author, 2015.

The Sanford B. Epstein caretaking company believes that rehabilitation would require the following: (1) repair of all toppled stones by fixing foundations and resetting the markers using epoxy; (2) repair of all sidewalks and roadways; (3) repair all fencing and replacement of gates to improve security; and (4) dismantling disintegrated archways. Internal hazards cause part of the safety issue, for example, the toppled stones and the broken sidewalks and paths. Three major challenges face proper maintenance: (1) the passing of the older generation who cared for the

\footnotetext{
${ }^{31}$ Judy Salomon, 2015. Email to author, October 30.
} 
graves of their loved ones; (2) discontinued care by the younger generation who likely do not live in the area and would not visit the site; and (3) settled foundations that cause the stones to tip or fall, debris, and deterioration of the sidewalks and paths. However, burials still continue to take place.

Fern Epstein points out, “...a lot of the tradition of going to the cemetery is not passed down...children are not brought because we don't want them to be sad or we don't want the children to know or walk through an old cemetery." She also posits that those graves under perpetual care are visibly different from those without it. She also notes that weeding requires a manual approach, because no tractor could navigate or pass through the grounds. Uprighting downed stones is the responsibility of the interred's family, she says: “... what happens if and when it fell on the ground and it got chipped and the cemetery comes along and puts it upright and the family comes along and says, 'Look what you did to my monument?' So the cemetery has to stand away..." 32 The stones are made of granite, by cemetery mandate. While Epstein notes that the graves fall due to age, there are much older cemeteries, such as the fourteenth-century Jewish cemetery in Prague, where the stones still stand upright. The Beth El Memorial Park Foundation's allocation of several thousand dollars for repairs and emergency support are not sufficient.

Ownership of the "cemetery problem" has transitioned to the organized Jewish community in the form of the Jewish Federation of MetroWest NJ from individual cemetery sections. The New Jersey Jewish News reported in 2014, "When the synagogues and burial societies that ran the cemeteries closed down, maintenance of the historic cemeteries became a community responsibility." 33 The term "community" is broad and requires definition within categories of "insiders" and "outsiders." "Insiders" comprise the Jewish community: the interred and their

\footnotetext{
${ }^{32}$ Fern Epstein, interview with author.

33 Johanna Ginsberg, "Cemetery Guardian."
} 
descendants, the caretakers, the burial societies and synagogues, and the Jewish Federation. Among the interred are "big names," Sandford Epstein reported in 2012, although he did not name them. He said, "They were very important people in the city of Newark. But their shuls are now out of business." He informed reporters that the Jewish Federation "is starting discussions on how to figure out a long-term plan." 34

That plan is presumably the Community Association for Jewish At-Risk Cemeteries. Melanie Roth Gorelick, director of the Jewish Federation's CRC, told reporters, "It is imperative to maintain and have respect for our Jewish roots and we believe the cemeteries are important to maintain." 35 Fern Epstein relates that the cemetery office receives calls from as far away as Montana and Nebraska asking about grandparents or great-grandparents buried at Grove Street.

A symbiotic relationship exists between the cemetery property and the surrounding area. Homes bordering the Grove Street cemetery range from those with boarded-up windows to the newly renovated. Nearby businesses once included the Hoffman soda factory, which became the home to Pabst Beer in 1945 . That factory closed and was demolished by 2009 , including the iconic beer bottle that was visible from the Garden State Parkway. A revitalization plan calls for construction of thirty homes and a commercial shopping center on that site. The desire to transform the property persists. The Newark Community Economic Development Corporation requested proposals from developers in December 2015 to create a mixed-use commercial and residential area.

In 2013 a report surfaced of a 75-year-old man attacked at the cemetery. He had come with his wife to visit a gravesite at Grove Street's Adas Israel section when two males grabbed him, choked him, slashed him, and stole his car. A rabbi said of the event, "It should be a place for

\footnotetext{
${ }^{34}$ Robert Wiener, "Cemetery Day."

${ }^{35}$ Robert Wiener, "Cemetery Day."
} 
people to respect, instead of such a heinous crime." 36 The unidentified East Hanover victim did not heed the warning on the International Jewish Cemetery Project's website urging visitors to schedule their visits only on the annual Newark Cemetery visiting day. In 2013 that day was September 8.

The annual visiting day became a mecca for volunteers. Starting in 1995, Alice Gould, representing the North Jersey Jewish Genealogical Society of Wayne, gathered volunteers to record and index information found on the gravestones. They recorded the name in English (and Hebrew, if available), date of birth, date of death or age, whichever was available. Gould noted the first and last name of each row. ${ }^{37}$ The effort was also sponsored by the International Society of Jewish Genealogical Societies as part of its mission to collect information about every Jewish cemetery in the world. Gould's effort ceased in 2005 and produced data for nearly 27,000 graves in the Newark area, including but not limited to Grove Street. The caretakers maintain that Gould's efforts helped by supplying additional information to the records previously managed by organizations and synagogues.

Gould and her stalwart team clearly missed preservation opportunities. According to the standard guide for cemetery preservationists by Lynette Strangstad, it is not uncommon for volunteer groups to spring up and proceed without expert guidance, operating on the theory that it is better to do something than nothing. As Strangstad attests, there is much value to be gained from studying the stones. But Gould did not record the composition, condition, shape, or ornamentation of the gravestones, nor were photos taken. Clearly, she had taken on an overwhelming task. Securing local volunteers, especially those with knowledge of Hebrew, could not have been easy.

\footnotetext{
36 "NJ_Elderly Jewish Man Beaten, Carjacked at Newark Cemetery," T.O.T. Private Consulting, September 20, 2013, accessed October 23, 2015, http://privateinvesigations.blogspot.com/2013/09/nj-elderly-jewish-man-beatencarjacked.html.

${ }^{37}$ Rows continued through separate sections.
} 
They came from the community at large as well as from the North Jersey Genealogical Society. Gould shrewdly worked together with the Federation, but she did not follow the precedent of the 1970s task force.

The Jewish Federation has been tackling the "cemetery problem" since 1965, and yet none of its committees and task forces have been able to effectively resolve the problem. With the current Community Association in place, it could use the assistance of a preservation expert, one with a specialization in cemeteries. It is unclear whether the Newark Historic Preservation Commission plays or will play a role. ${ }^{38}$ The association should develop a cemetery preservation plan that would identify ownership of the cemetery's sections, determine the level of security existing and level needed to undertake a preservation program, complete the inscription transcription Gould started, determine the restoration work or conservation work required and the associated cost, determine sources of funding, and identify requirements for landscaping. Having the preservationist on hand would prevent any further missed opportunities.

New millennium tools could prove useful to funding and promotional efforts. For example, outreach could be achieved through social media and JewishGen.org, perhaps by interns. A dedicated website would also be helpful. Crowdsourcing could raise necessary funds. ${ }^{39}$ It would be critical to identify and reach the families of the interred. This could be achieved with the help of JewishGen.org and the network of Jewish genealogical societies around the country and the world.

Local designation is imperative. In her example of Minnesota's Bruce Vento Nature Sanctuary, Lisa Rainey Brownell states, "We examine values in places because people matter;

\footnotetext{
${ }^{38}$ Efforts by the author to reach Perris Straughter at the Newark Historical Preservation Commission were not successful.

${ }^{39}$ Much like Joseph Pulitzer's call to action through his newspaper to raise necessary funds to build and erect the Statue of Liberty's pedestal, a grass-roots funding initiative may indeed be more effective than other efforts.
} 
their stories matter, and knowing them more deeply can lead to the development of places that resonate more deeply within a community, that fully embrace what communities most value."40 The Jewish community has taken a major step forward by referring to Grove Street and the other neglected Jewish cemeteries as "Newark Jewish Historical Cemeteries." Branding, even without designation, is critical to value creation, legacy building, and perception management.

The people buried at Grove Street matter and their stories matter. The Federation, through New Jersey Jewish News and other forms of communication, needs to promote the people and their narratives. Through the Newark Historic Preservation Commission, the Federation should seek local designation. It is long overdue. Kaufman asserts that a storyscape could provide the rationale for a historic district. The African American Burial Ground in Manhattan may be useful in positioning the Grove Street Cemetery as a "historically derived sense of place."41

The Grove Street Cemetery has been a constant source of cultural heritage, family history, and preservation concerns for more than fifty years. The ownership issue appears to have been finally resolved by the Jewish Federation of MetroWest NJ and the establishment of a Community Association with a preservation mission. Whether it will prove to be effective remains to be seen.

Values inherent in the project do not seem to be at odds between the stakeholders. A single, focused mission guides the association. Yet families of the interred need to play a larger role, because it is their deceased loved ones at the heart of the preservation concerns, and as Meyer Fine pointed out in 1975, it is ultimately their responsibility to resolve on a grave-by-grave basis.

Since the 1960s, the Jewish Federation has shown a well-intentioned but haphazard commitment to honor the dead and the legacy, but it suffers from a lack of preservation expertise.

\footnotetext{
${ }^{40}$ Lisa Rainey Brownell, "Values in Place: Exploring Community Values at the Bruce Vento Nature Sanctuary," Material Culture 43, No. 2 (2011), 39.

${ }^{41}$ Kaufman, Place, Race, and Story, 61.
} 
Still, the Federation exemplifies the Jewish value of taking care of its own. By working in partnership with the "outside" agency of the Newark Historic Preservation Commission, it may be able to take perpetual care of the cemetery problem. Together, they can leave no stone unturned.

Barbara Krasner is an independent scholar focusing on American Jewish history. She holds an undergraduate degree in German from Douglass College, a master's in business administration from Rutgers University, a master's in writing from Vermont College of Fine Arts, and a master's in history from William Paterson University, where she teaches as an adjunct in the English and History departments. 